\title{
Morpho-anatomical variation and their phylogenetic impli- cations in native and exotic species of Pinus L. growing in the Indian Himalayas
}

\author{
Lav Singh ${ }^{1,4}$, Pooja Dixit ${ }^{1}$, Ravi Prakash Srivastava ${ }^{1}$, Shivaraman Pandey ${ }^{2}$, Praveen Chandra Verma ${ }^{3}$ Gauri \\ Saxena ${ }^{1}$ \\ 1 Department of Botany, University of Lucknow, Lucknow, India. \\ 2 Plant Diversity, Systematics and Herbarium Division, CSIR-National Botanical Research Institute, Lucknow, India. \\ 3 Plant Molecular Biology and Genetic Engineering Division, CSIR-National Botanical Research Institute, Lucknow, India. \\ 4 Department of Botany, R. D. and D. J. College, Munger University, Munger 811-201, India.
}

\section{Correspondence}

G. Saxena

E-mail: gaurigupta72@yahoo.com

Received: 15 March 2020

Accepted: 23 June 2020

Published on-line: 7 July 2020

\section{Resumen}

Variaciones morfoanatómicas y sus implicaciones filogenéticas en especies nativas y exóticas de Pinus L. del Himalaya indio

Se realizó un estudio anatomico completo y detallada de agujas en diez especies de Pinus utilizando nueve rasgos morfológicos y anatómicos. Los datos pueden usarse como una herramienta para la identificación y clasificación de Pinus hasta el nivel de género y especie. También encontramos que la similitud y las diferencias en los rasgos anatómicos de la hoja respaldaban la filogenia molecular de Pinus realizada por varios investigadores.

Palabras clave: Pinus; Acícula; Fascículo; Haz vascular; Phylogenia.

\begin{abstract}
Comprehensive and detailed anatomy of needles in ten species of Pinus using four morphological traits and nine anatomical traits was carried out. The data can be used as a tool for identification and classification of Pinus upto genus and species level. We also found that similarity and differences in leaf anatomical traits supported the molecular phylogeny of genus Pinus conducted by several researchers.
\end{abstract}

Key words: Pinus; Needles; Fascicles; Vascular bundle; Phylogeny.

\section{Introduction}

Order Pinales represents an outstanding group of gymnosperms and is omnipresent in terrestrial habitat. These monoecious woody plants usually grow naturally or have been introduced in both the hemispheres, mainly in the Northern hemisphere sometimes occurring in subtropical and tropical regions of Central America and Asia. They may form forest or co-exist with other trees (Farjon 1984 \& 2005, Gaussen et al. 1993). They have received much attention in past few years because they form a major component of many temperate forests, and not only have ecological implications but are also of economical significance as a source of timber, pulp and paper, nuts, 
seeds, resins, construction materials, and other byproducts (Richardson \& Rundel 1998).

Genus Pinus L. is a large group of different pine species in Indian Himalayas with high medicinal value and has played a significant role in maintaining health (Sharma et al. 2018). Genus Pinus is the largest genus in the family of coniferous trees with broad climate adaptability. Genus Pinus has 110 species (Gernandt et al. 2005) and is usually divided into two subgenera, Strobus (D. Don) Lemmon (soft pines) and Pinus L. (hard pines), which are further divided into sections and subsections (Little \& Critchfield 1969, Gernandt et al. 2005). The taxonomic history of the genus was reviewed by Price et al. (1998), that included morphology, anatomy, crossability, cytology, secondary metabolites, DNA and protein comparisons. The morphological traits that distinguish various species from each other include characters like the length and width of needles, the number of needles per fascicle, arrangement and orientation of needles (pendulous or erect), and anatomical characteristics like epidermal cells, number and position of resin ducts, and number of vascular bundles in the needle (Gernandt et al. 2005).

It has been observed that morphological and anatomical traits of needles as well as wood are strongly controlled by environmental conditions like temperature, light availability and moisture content in the habitat (Abrams \& Kubiske 1990, Dixit et al. 2016). These morphological as well as anatomical differences could provide new information that can be used to establish phylogenetic relationship among various species (Ghimire et al. 2014). Although the needle structure of the common conifers like that of genus Pinus is comparatively well studied and known, a comprehensive treatment of the comparative histological organization of the needles is still lacking. The main focus of present work was to perform a detailed anatomical study of needles from native Indian and cultivated species of genus Pinus to make a detailed histological comparison of selected Pinus species. In our study, we found a high level of morphological variability among native and exotic species as well as within their population particularly needle traits like needle length that shows a higher degree of variation. Same is also true for plant height and bark colour. Further, the individual has a specific norm of reactions to environmental factors and has a capacity for certain morphological modifications within a specific range. The data generated was further used to draw evolutionary relationship among these ten exotic and indigenous species of genus Pinus namely Pinus merkusii Jungh. \& de Vriese, Pinus kesya (Basionym of Pinus insularis Endl. ), Pinus taeda L., Pinus elliottii Engelm., Pinus echinata Miller, Pinus thunbergii Parl., Pinus patula Schiede ex Schlectendahl et Chamisso, Pinus greggii Engelm, Pinus wallichiana A.B. Jackson and Pinus roxburghii Sargent.

\section{Materials and methods}

\section{Sample collection}

Altogether 150 observation by analysing 30 plant samples ( 3 trees for each species and five needles per tree), comprising 10 pine species (Table 1) were collected using random block design (RBD) in September, 2016, from a cultivated population in the region of Ranikhet (located at $357 \mathrm{~km} \mathrm{NSE}$ of New Delhi (Fig. 1); 29³9'52.2"N, 79²8' 40.9"E; altitude 1,727 m.a.s.1.). The site is characterized by an average temperature of $14.4^{\circ} \mathrm{C}$, average rainfall (about $1,575 \mathrm{~mm}$ of annual precipitation) and low soil fertility. A voucher specimen of all the species selected for study was deposited in the herbarium of the National Botanical Research Institute (NBRI), Lucknow (India) and identified.

\section{Methodology for morpho-anatomical studies}

Tree height was measured using stick method and other macroscopic and microscopic analysis were performed at the laboratory. Needle length was measured (Table 1) using a measuring scale, whereas other anatomical characteristics were observed (Table 2, Fig. 2) under the microscope (Nikon Eclipse 80i). For morphological studies, parameters like a number of needles per fascicle and needle length were taken. The other morphological characters taken into account included the height of the plant and bark color. For anatomical studies, fresh plant needles were collected from Pinus species under study. The microtome sectioning (using Radical Di-cast Microtome, RMT20A) and processing of needles was done according to the procedure given by Federica \& Ruzin (2000). Fresh needles were fixed in a formalinacetic acid solution $(50 \mathrm{ml} \mathrm{95 \%}$ ethanol, $5 \mathrm{ml}$

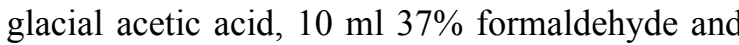
$35 \mathrm{ml}$ distilled water) and kept for 24 hours 


\begin{tabular}{|c|l|c|c|c|c|}
\hline Sample code & Pinus species & $\begin{array}{c}\text { Height } \\
\text { (in meters) }\end{array}$ & Bark color & $\begin{array}{c}\text { No of needle } \\
\text { per fascicles }\end{array}$ & $\begin{array}{c}\text { Size of needle } \\
\text { (in cm) }\end{array}$ \\
\hline$P M$ & Pinus thunbergii $^{*}$ & $27-39$ & Greyish brown & 2 & $10.66 \pm 3.3$ \\
\hline$P R$ & Pinus roxburghii $^{*}$ & $45-54$ & Dark grey & 3 & $29.97 \pm 6.8$ \\
\hline$P W$ & Pinus wallichiana* $^{*}$ & $15-46$ & Greyish brown & 5 & $15.49 \pm 4.8$ \\
\hline$P M$ & Pinus merkusii* $^{*}$ & $14-18$ & Grey to brown & 2 & $21.59 \pm 4.0$ \\
\hline$P K$ & Pinus kesya $^{*}$ & $30-46$ & Light brown & 3 & $18.54 \pm 1.2$ \\
\hline$P T d$ & Pinus taeda & $28-34$ & Reddish brown & 3 & $14.98 \pm 2.7$ \\
\hline$P E$ & Pinus echinata & $25-37$ & Reddish & 2 & $35.56 \pm 2.5$ \\
\hline$P G$ & Pinus gregii & $12-15$ & Grey & 3 & $13.2 \pm 4.3$ \\
\hline$P P$ & Pinus patula & $12-19$ & Reddish brown & 3 & $20.06 \pm 4.3$ \\
\hline$P E I$ & Pinus elliottii & $18-30$ & Greyish brown & 2 & $21.08 \pm 3.3$ \\
\hline
\end{tabular}

*Pine species native to India

Tabla 1. Especies de Pinus seleccionadas en los Himalayas noroccidentales y análisis de sus rasgos morfológicos.

Table 1. Selected species of Pinus in nortwestern Himalayas and morphological trait analysis.

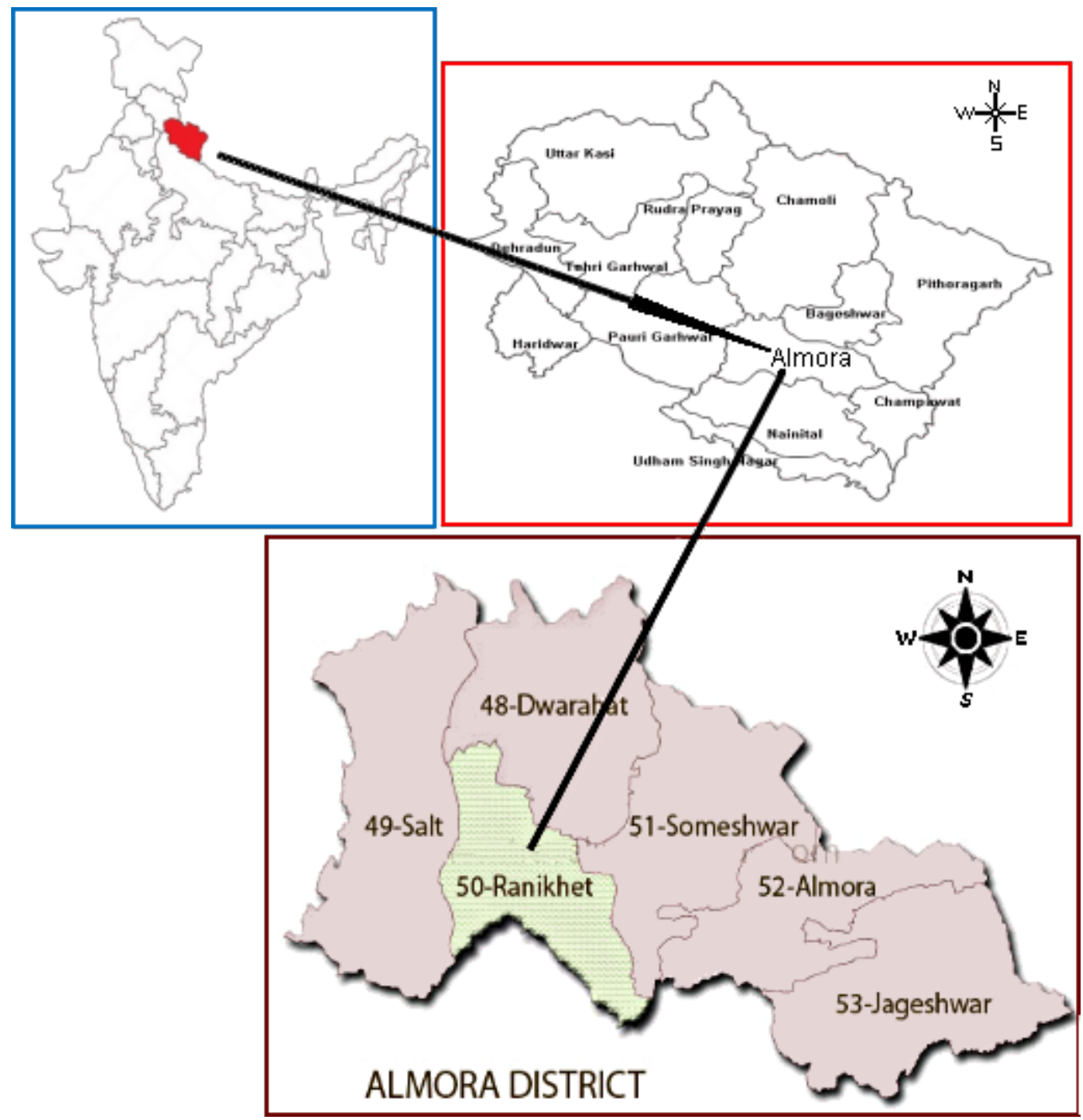

Figura 1. Mapa que muestra el área de donde provienen las especies de Pinus que han sido recolectados durante el presente estudio (Uttarakhand, India).

Figure 1. Map showing area from where the species of Pinus have been collected during present study (Uttarakhand, India). 


\begin{tabular}{|l|l|l|l|l|l|}
\hline $\begin{array}{l}\text { Needle } \\
\text { characteristics }\end{array}$ & \multicolumn{1}{|c|}{$\begin{array}{c}\text { Pinus } \\
\text { roxburghii }\end{array}$} & $\begin{array}{c}\text { Pinus } \\
\text { wallichiana }^{*}\end{array}$ & $\begin{array}{c}\text { Pinus } \\
\text { merkusii }^{\star}\end{array}$ & \multicolumn{1}{c|}{$\begin{array}{c}\text { Pinus } \\
\text { kesya }^{*}\end{array}$} & $\begin{array}{c}\text { Pinus } \\
\text { thunbergii }\end{array}$ \\
\hline 1. NT $(\mu \mathrm{m})$ & $771.93 \pm 9.6^{\mathrm{a}}$ & $438.60 \pm 2.38^{\mathrm{h}}$ & $664.34 \pm 3.46^{\mathrm{b}}$ & $495.74 \pm 9.98^{\mathrm{f}}$ & $501.36 \pm 2.80^{\mathrm{f}}$ \\
\hline 2. NW $(\mu \mathrm{m})$ & $1174.88 \pm 1.99^{\mathrm{b}}$ & $755.76 \pm 6.51^{\mathrm{i}}$ & $1265.81 \pm 16.19^{\mathrm{a}}$ & $869.80 \pm 2.96^{\mathrm{g}}$ & $1267.32 \pm 3.40^{\mathrm{a}}$ \\
\hline 3. C+ET $(\mu \mathrm{m})$ & $10.32 \pm 0.36^{\mathrm{f}}$ & $12.13 \pm 0.57^{\mathrm{e}}$ & $18.90 \pm 0.54^{\mathrm{a}}$ & $10.42 \pm 0.73^{\mathrm{f}}$ & $12.18 \pm 0.80^{\mathrm{e}}$ \\
\hline 4. ECW $(\mu \mathrm{m})$ & $11.68 \pm 0.57^{\mathrm{c}}$ & $12.71 \pm 0.37^{\mathrm{c}}$ & $15.24 \pm 0.64^{\mathrm{b}}$ & $17.01 \pm 0.49^{\mathrm{a}}$ & $12.77 \pm 1.13^{\mathrm{c}}$ \\
\hline 5. ENCT $(\mu \mathrm{m})$ & $24.40 \pm 0.69^{\mathrm{a}}$ & $17.79 \pm 0.69^{\mathrm{bc}}$ & $22.96 \pm 1.46^{\mathrm{a}}$ & $17.94 \pm 1.91^{\mathrm{b} . \mathrm{c}}$ & $18.40 \pm 1.00^{\mathrm{bc}}$ \\
\hline 6. ENCW $(\mu \mathrm{m})$ & $45.59 \pm 2.45^{\mathrm{b}}$ & $35.37 \pm 0.78^{\mathrm{f}}$ & $41.77 \pm 1.32^{\mathrm{b}}$ & $29.65 \pm 1.38^{\mathrm{g}}$ & $38.15 \pm 1.82^{\mathrm{e}}$ \\
\hline 7. VBT $(\mu \mathrm{m})$ & $446.55 \pm 3.98^{\mathrm{a}}$ & $239.81 \pm 2.37^{\mathrm{h}}$ & $363.29 \pm 2.15^{\mathrm{d}}$ & $240.62 \pm 0.73^{\mathrm{g}, \mathrm{h}}$ & $301.34 \pm 3.97^{\mathrm{d}}$ \\
\hline 8. VBW $(\mu \mathrm{m})$ & $681.61 \pm 3.98^{\mathrm{b}}$ & $252.06 \pm 4.49^{\mathrm{j}}$ & $701.05 \pm 3.26^{\mathrm{a}}$ & $401.50 \pm 1.30^{\mathrm{g}}$ & $288.77 \pm 2.69^{\mathrm{i}}$ \\
\hline 9. RCD $(\mu \mathrm{m})$ & $61.50 \pm 2.57^{\mathrm{a}}$ & $40.57 \pm 1.27^{\mathrm{e}}$ & $57.85 \pm 1.11^{\mathrm{b}}$ & $41.62 \pm 2.16^{\mathrm{e}}$ & $40.34 \pm 1.00^{\mathrm{e}}$ \\
\hline
\end{tabular}

\begin{tabular}{|l|l|l|l|l|l|}
\hline $\begin{array}{l}\text { Needle } \\
\text { characteristics }\end{array}$ & \multicolumn{1}{|c|}{$\begin{array}{c}\text { Pinus } \\
\text { taeda }\end{array}$} & $\begin{array}{c}\text { Pinus } \\
\text { echinata }\end{array}$ & $\begin{array}{c}\text { Pinus } \\
\text { greggii }\end{array}$ & $\begin{array}{c}\text { Pinus } \\
\text { patula }\end{array}$ & \multicolumn{1}{|c|}{$\begin{array}{c}\text { Pinus } \\
\text { elliottii }\end{array}$} \\
\hline 1. NT $(\mu \mathrm{m})$ & $645.66 \pm 2.74^{\mathrm{c}}$ & $578.44 \pm 2.59^{\mathrm{e}}$ & $607.09 \pm 4.61^{\mathrm{d}}$ & $485.27 \pm 4.10^{\mathrm{g}}$ & $502.48 \pm 3.05^{\mathrm{f}}$ \\
\hline 2. NW $(\mu \mathrm{m})$ & $1024.17 \pm 5.41^{\mathrm{c}}$ & $972.70 \pm 2.30^{\mathrm{e}}$ & $847.96 \pm 3.44^{\mathrm{h}}$ & $899.49 \pm 2.40^{\mathrm{f}}$ & $1011.89 \pm 2.57^{\mathrm{d}}$ \\
\hline 3. C+ET $(\mu \mathrm{m})$ & $13.84 \pm 0.25^{\mathrm{d}}$ & $17.37 \pm 0.33^{\mathrm{b}}$ & $19.42 \pm 0.43^{\mathrm{a}}$ & $14.96 \pm 0.09^{\mathrm{c}}$ & $11.68 \pm 0.33^{\mathrm{e}}$ \\
\hline 4. ECW $(\mu \mathrm{m})$ & $12.40 \pm 0.64^{\mathrm{c}}$ & $14.83 \pm 0.85^{\mathrm{b}}$ & $11.68 \pm 0.62^{\mathrm{c}}$ & $16.80 \pm 0.30^{\mathrm{a}}$ & $15.08 \pm 0.51^{\mathrm{b}}$ \\
\hline 5. ENCT $(\mu \mathrm{m})$ & $16.74 \pm 0.83^{\mathrm{c}}$ & $23.32 \pm 0.98^{\mathrm{a}}$ & $19.23 \pm 0.49^{\mathrm{b}}$ & $11.72 \pm 0.46^{\mathrm{e}}$ & $14.00 \pm 0.27^{\mathrm{d}}$ \\
\hline 6. ENCW $(\mu \mathrm{m})$ & $51.61 \pm 0.78^{\mathrm{a}}$ & $43.04 \pm 1.16^{\mathrm{cd}}$ & $41.00 \pm 1.09^{\mathrm{d}}$ & $46.65 \pm 0.79^{\mathrm{b}}$ & $43.39 \pm 1.16^{\mathrm{cd}}$ \\
\hline 7. VBT $(\mu \mathrm{m})$ & $324.69 \pm 3.16^{\mathrm{b}}$ & $269.88 \pm 1.16^{\mathrm{e}}$ & $266.11 \pm 4.96^{\mathrm{e}}$ & $255.71 \pm 2.87^{\mathrm{f}}$ & $245.69 \pm 1.26^{\mathrm{g}}$ \\
\hline 8. VBW $(\mu \mathrm{m})$ & $481.63 \pm 1.91^{\mathrm{f}}$ & $603.12 \pm 2.70^{\mathrm{c}}$ & $390.16 \pm 1.34^{\mathrm{h}}$ & $580.29 \pm 0.94^{\mathrm{c}}$ & $595.22 \pm 2.55^{\mathrm{d}}$ \\
\hline 9. RCD $(\mu \mathrm{m})$ & $55.07 \pm 1.15^{\mathrm{bc}}$ & $55.31 \pm 0.53^{\mathrm{c}}$ & $50.21 \pm 1.48^{\mathrm{d}}$ & $53.84 \pm 0.74^{\mathrm{c}}$ & $34.18 \pm 1.12^{\mathrm{f}}$ \\
\hline
\end{tabular}

Tabla 2. Rasgos anatómicos de agujas en las especies de Pinus seleccionadas. Las letras indican diferencias significativas entre los diferentes rasgos de cada parámetro por separado utilizando las pruebas de rango múltiple de Duncan $(\mathrm{DMRT})(\mathrm{p}<0.05, \mathrm{ANOVA}, \mathrm{n}=3)$. NT: espesor de la aguja; NW: ancho de aguja; C+ET: grosor cuticular + epidérmico; ECW: ancho de la célula de la epidermis; ENCT: grosor de la célula de endodermis; ENCW: ancho de la célula de endodermis; VBT: grosor del haz vascular; VBW: ancho del haz vascular; RCD: diámetro del canal de resina. Media \pm desviación estándar, $\mathrm{n}=3$

Table 2. Anatomical traits of needles in selected Pinus species. Letters indicate significant differences between different traits each parameter separately using Duncan multiple range tests (DMRTs) $(\mathrm{p}<0.05$, ANOVA, $\mathrm{n}=3)$. NT: needle thickness; NW: needle width; C+ET: cuticular + epidermal thickness; ECW: epidermis cell width; ENCT: endodermis cell thickness; ENCW: endodermis cell width; VB:, vascular bundle thickness; VBW: vascular bundle width; RCD: resin canal diameter. Mean $\pm \mathrm{SD}, \mathrm{n}=3$.

for $35 \mathrm{ml}$ distilled water) and kept for 24 hours for fixation. Before the final dehydration process, the fixed tissue was slightly warmed in $1 \%$ sodium hydroxide. In this step, needles were treated with an increasing gradient of a mixture of ethanol, tert-butanol, and water starting from $10 \%$ tert-butanol and ending at $100 \%$ tert-butanol. The samples were kept in each grade for a minimum of 35 minutes. After dehydration, the samples were transferred into wax containers where the wax was kept at $60-65{ }^{\circ} \mathrm{C}$ temperature in an oven. Molten wax was changed at a regular interval of 30 minutes with the addition of fresh wax. In this step, freshly molten wax was poured in the cubic space formed by attaching two L Blocks. Then the samples, which were previously treated with wax, were inserted vertically in the semisolid wax and wax block with the embedded tissue was allowed to cool followed by separation of L-Blocks. The wax cubes with the embedded specimen were then fixed to wooden blocks to get them attached to the microtome consequently. The attached wax blocks were then subjected to section cutting using microtome and sections were cut between 8-12 $\mu \mathrm{m}$ depending upon the hardness of the samples.

\section{Preparation of slides}

The wax films of determined thickness were scooped out on a slide coated with a layer of a mixture of egg albumin and glycerol, which acts as an adhesive. The slide containing the paraffin film was then gently warmed and dipped in a jar containing xylene and was kept till all the wax gets solubilized in xylene. The slide was treated with alcohol solution starting from a concentration of $95 \%$, then $90 \%, 80 \%, 70 \%$ and finally $50 \%$. The slide was then stained with safranin solution $(0.5 \%)$ and was kept for $12-15$ minutes depending on nature and thickness of the sample. The slides were further treated with an increasing grade of ethanol starting from $50 \%$ and ultimately ending in $90 \%$ followed by staining with the fast 

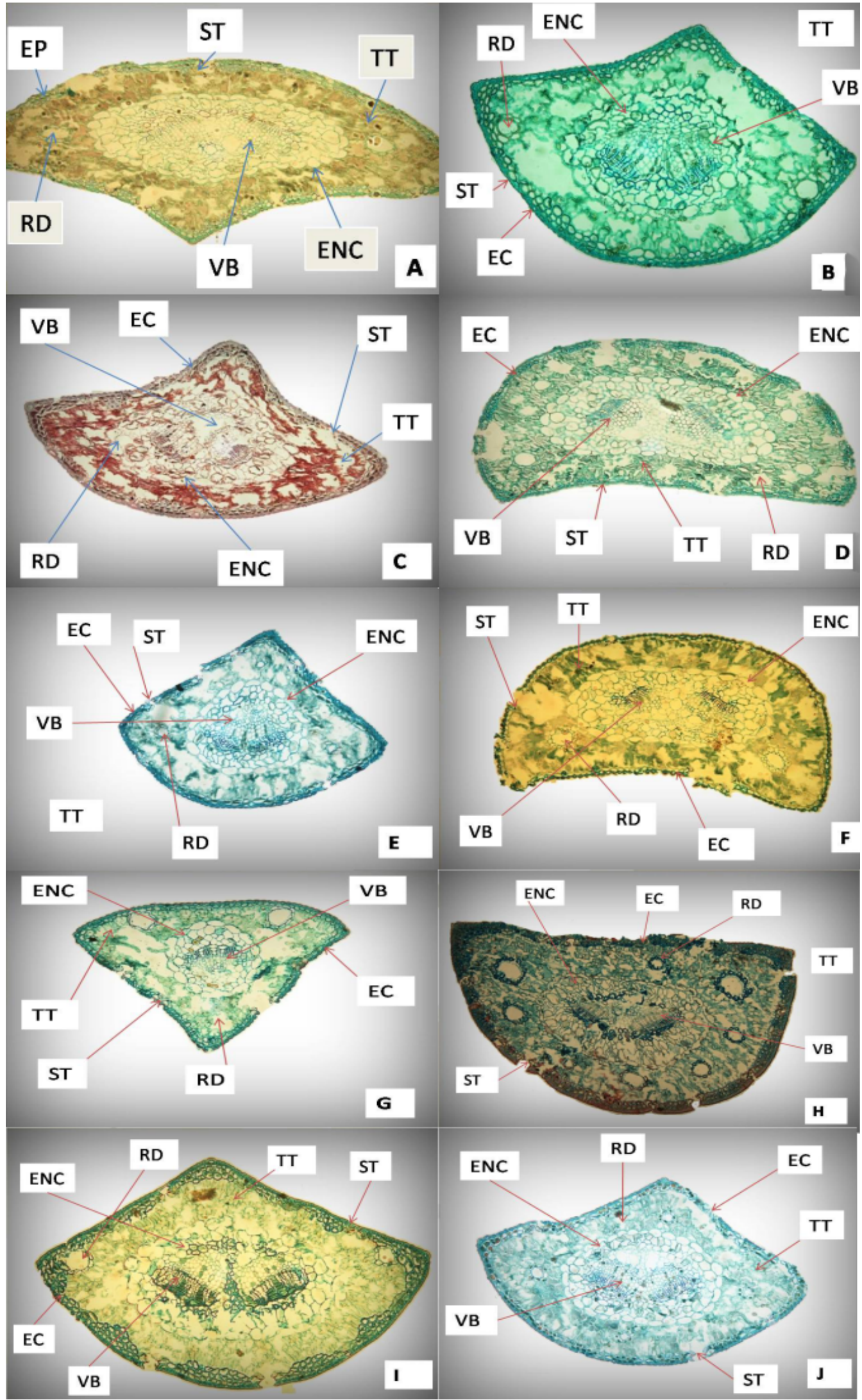

Figura 2. A: P. merkusii; B: P. kesya; C: P. elliottii; D: P. echinata; E: P. taeda; F: P. patula; G: P. wallichiana; H: P. thunbergii; I: P. roxburghii; J: P. greggii. CE: célula epidérmica; ENC: célula endodérmica; RD: conducto de resina; TT: tejido de transfusión; ST: estomas; VB: haz vascular.

Figure 2. A: P. merkusii; B: P. kesya; C: P. elliottii; D: P. echinata; E: P. taeda; F: P. patula; G: P. wallichiana; H: P. thunbergii; I: $P$. roxburghii; J: P. greggii. EC: Epidermal cell; ENC: Endodermal cell; RD: resin duct; TT: Transfusion tissue; ST: stomata; VB:vascular bundle. 
green solution $(0.1 \%)$. Slides were eventually washed with $95 \%$ ethanol to clear any excess stain in the section. They were dried, and the prepared sections were mounted on DPX and covered with a cover slip attentively avoiding any air bubble. Investigations and measurements of all selected anatomical traits were carried out on needles of all ten species of Pinus using the light microscope fitted with a Nikon digital camera in National Botanical Research Institute (NBRI). The slides of each of the studied plant parts were examined under a microscope; the eye piece lens was $(\times 10)$ whereas the objective lenses were $(\times 4$ and $\times 20)$.

\section{Statistical analysis}

All samples were analyzed in triplicates, and their mean and standard deviation (SD) were calculated accordingly. Variation in anatomical traits were compared by using one way analysis of variance (ANOVA), followed by Duncan multiple range test (DMRT) using SPSS16. 0 software. The dendrogram was generated using the nearest neighbor method, squared Euclidean distance measure, based on differences between measurements of anatomical traits using Statgraphics Plus version 5.0 (Statistical Graphics Corporation, Princeton, NJ, USA). Principal components analysis (PCA) was applied to scale data and evaluate the underlying dimensionality of the variables and to elucidate the relationship among selected traits using Past v software.

\section{Results and discussion}

The results of the morphological and anatomical (Tables $1 \&$ 2, Fig. 2) studies on various traits of Pinus needles have been summarized below.

\section{Morphological traits analysis}

The analyzed populations of species were significantly different with respect to most of the selected traits (Table 1). Maximum difference was observed in the height of plants which varied from an average of approximately $15.24 \mathrm{~m}$, in $P$. merkusii, to an average of $47.24 \mathrm{~m}$, in $P$. roxburghii. Similarly, a number of needles per fascicles varied from about 2 to 5 most common being 3 and length of needles varied from $10.16 \mathrm{~cm}$ as in P. echinata and P. thunbergii to a maximum of about $30.48 \mathrm{~cm}$ in $P$. roxburghii. Variations were also observed in bark colour of identified Pinus species which varied from light brown in $P$. kesya to dark grey in P. roxburghii.

\section{Anatomical traits analysis}

A total of nine anatomical traits were taken into consideration, including needle thickness (NT); needle width (NW); cuticle and epidermal thickness $(\mathrm{C}+\mathrm{ET})$; epidermal cell width (ECW); endodermis cell thickness (ENCT); endodermis cell width (ENCW); vascular bundle thickness (VBT); vascular bundle width (VBW); resin canal diameter (RCD). Results of anatomical studies (Table 2) in needles of selected species of genus Pinus suggested significant variations in terms of needle width, needle thickness, vascular bundle width and thickness, thickness and width of epidermal cell and diameter of resin duct. Needle thickness (NT) was maximum in $P$. roxburghii $(771.93 \mu \mathrm{m})$ while minimum was in $P$. wallichiana $(438.60$ $\mu \mathrm{m})$. Among exotic species, needle thickness was maximum in P. taeda $(645.66 \mu \mathrm{m})$. The width of the needle (NW) was maximum in $P$. thunbergii $(1267.32 \mu \mathrm{m})$ while minimum was in $P$. wallichiana $(755.76 \mu \mathrm{m})$. Among exotic species, maximum needle width was reported in $P$. taeda $(1024.17 \mu \mathrm{m})$. Similarly, C+ET was maximum in P. greggii $(19.42 \mu \mathrm{m})$ while it was least in $P$. roxburghii $(10.32 \mu \mathrm{m})$. Among native species, it was maximum in P. merkusii $(18.90 \mu \mathrm{m})$. As far as the width of epidermal cells (ECW) was concerned, it was maximum in P. kesya $(17.01 \mu \mathrm{m})$ while minimum in $P$. greggii $(11.68 \mu \mathrm{m})$. Among exotic species, maximum width was reported in $P$. patula $(16.80 \mu \mathrm{m})$. The thickness of endodermal cells (ENCT) was maximum in $P$. roxburghii $(24.40$ $\mu \mathrm{m})$ while minimum in $P$. patula $(11.72 \mu \mathrm{m})$. Among exotic species, it was maximum in $P$. echinata $(23.32 \mu \mathrm{m})$. The width of endodermal cells (ENCW) was maximum in P. taeda (51.61 $\mu \mathrm{m})$ while minimum in $P$. kesya $(29.65 \mu \mathrm{m})$. Among native species, the maximum width of endodermal cells was observed in $P$. roxburghii $(42.59 \mu \mathrm{m})$. Two important vascular bundle traits were taken into considerations viz. vascular bundle thickness (VBT) and vascular bundle (VBW) width. Among native species, former was reported maximum in $P$. roxburghii $(446.55 \mu \mathrm{m})$ while minimum was in $P$. wallichiana $(239.81 \mu \mathrm{m})$ and later was reported maximum in $P$. merkusii $(701.05 \mu \mathrm{m})$ while minimum in $P$. wallichiana (252.06 $\mu \mathrm{m})$. Among exotic species, P. taeda showed maximum value for vascular bundle 
thickness $(324.69 \mu \mathrm{m})$, and it was minimum for $P$. elliottii $(245.69 \mu \mathrm{m})$ while vascular bundle width was maximum in P. echinata $(603.12 \mu \mathrm{m})$ and it was minimum for $P$. greggii $(390.16 \mu \mathrm{m})$. The diameter of resin duct was maximum in $P$. roxburghii $(61.50 \mu \mathrm{m})$ while minimum in $P$. elliottii $(34.13 \mu \mathrm{m})$. Among exotic species, P. echinata $(55.31 \mu \mathrm{m})$ showed the maximum diameter of resin duct.

Cluster analysis was conducted using all the anatomical traits understudy for selected species of pine needles (Fig. 3). It displayed similarities between $P$. merkusii and $P$. roxburghii and between $P$. wallichiana and P. kesya. The results of the PCA in the selected pine needles were obtained from nine anatomical characteristics (Fig. 4); 90 observations for each trait were processed in the correlation matrix. Each observation represented the average value of the properties analyzed in three needles per tree. PCA showed that the first two axes represent $65.76 \%$ of the information. Further, PCA visualises that NW (Needle width), NT (Needle thickness), VBT (Vascular bundle thickness) and ENT (Endodermal thickness) show similarity in $P$. roxburghii and $P$. taeda while C+ET (Cuticular plus epidermal thickness), VBW (Vascular bundle width), ENW (Endodermal width) and RCD (Resin canal diameter) show similarity in P. merkusii, P. echinata and P. taeda.

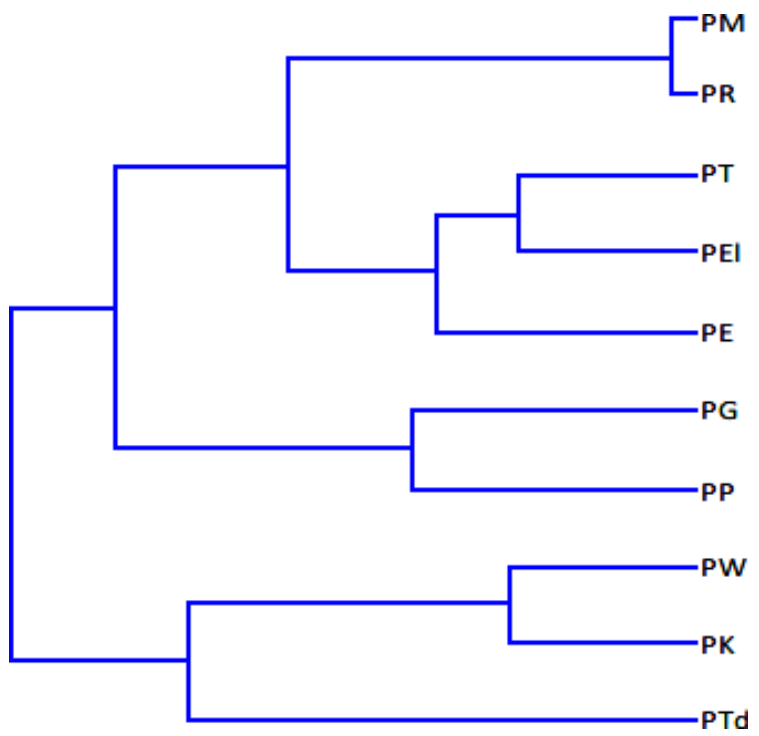

Figura 3. Dendrograma de nueve propiedades morfoanatómicas de especies seleccionadas de Pinus basadas en el "método vecino más cercano" con distancia euclidea al cuadrado.

Figure 3. Dendrogram of nine morpho-anatomical properties of selected species of Pinus based on a "nearest neighbor method" (squared Euclidean distance).

\section{Discussion}

Pines differ from other members of family Pinaceae and they are easily characterized by their dimorphic shoots that include long as well as short shoots called brachyblasts. These brachyblasts bear long, narrow needle-like leaves mostly present in groups of two to five. The species in the three sections and three subsections included in this study had two, three, or five needles per fascicle (Table 1). Two species from section Trifoliae and subsection Australes (P. taeda and P. echinata) had two needles per fascicle, whereas three taxa from the same section and subsection $(P$. greggii, $P$. patula, and $P$. elliottii) had three needles per fascicle (classification of Gernandt et al. 2005). On the other hand, two species of section Pinus (P. thunbergii and P. merkusii) had two needles per fascicle, whereas two taxa from the same section Pinus: P. roxburghii (subsection Pinaster) and P. kesya (subsection Pinus) had three needles per fascicle. Only one analysed taxa from section Quinquefoliae and subsection Strobus (P. wallichiana) had five needles per fascicles. The number of needles per fascicle has evolutionary significance too, as five needles per fascicle are considered to be a primitive character within Pinus as compared to two or three needles per fascicle (Kaundun \& Lebreton 2010).

Out of the ten taxa examined in our study, nine belonged to subgenus Pinus and one to subgenus Strobus. In terms of the internal anatomical structure of the needle, two subgenera were easily distinguishable by the number of vascular bundles, as species of subgenus Pinus have two fibrovascular bundles per needle and those of subgenus Strobus have only single fibrovascular bundles. Further presence of two versus one vascular bundle within a single bundle sheath has proven to be an important diagnostic feature for differentiating subgenera Strobus and Pinus within genus Pinus (Gernandt et al. 2005, Eckenwalder 2009).

The morpho-anatomical parameters across the populations also form an important attribute to assess growth performance and biomass (Jugrana et al. 2013). In Pinus, needles are the only assimilatory organs, having important effects on plant physiology as well as ecological adaptability (Nobis et al. 2012). Although most morphological and anatomical traits of needles remain stable at the species level, few previous researchers have demonstrated that genetic variations do exist 


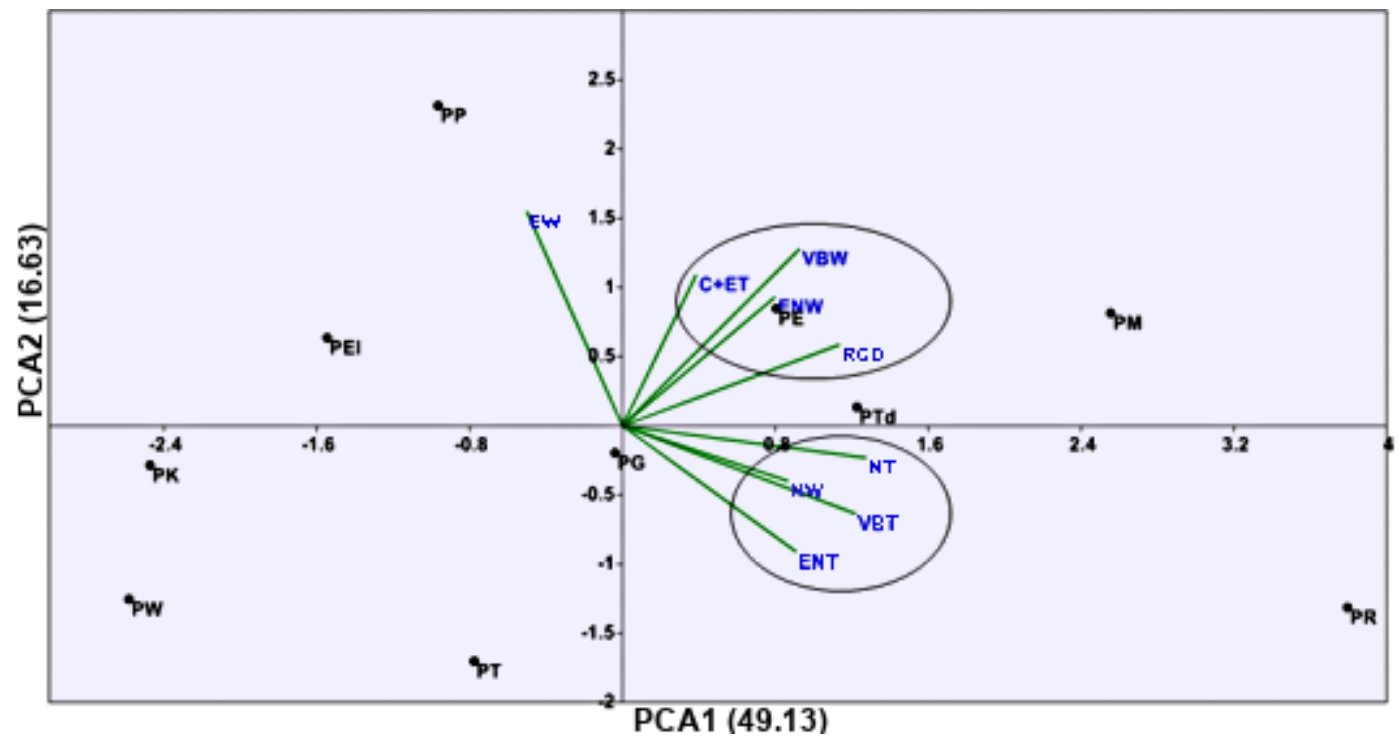

Figura 4. PCA de nueve propiedades morfoanatómicas de especies seleccionadas de Pinus.

Figure 4. PCA of nine morpho-anatomical properties of selected species of Pinus.

within them in general. Further, researchers have also discovered the adaptive features of needle traits in the environment (Legoshchina et al. 2013, Xing et al. 2014) and specially alpine environments can provide useful natural avenues to understand the response of plants to a suite of climatic conditions that are representative of the broader latitudinal range (Montesinos-Navarro et al. 2011).

In our study, we have selected nine anatomical traits including two traits from vascular system, i.e. vascular bundle width and vascular bundle thickness to see implications of these traits on the phylogeny of genus Pinus, and we encountered significant variations among populations that may indicate genetic differences (Table 2). However growing scientific evidence have shown that change in the internal structures of needles may be an outcome of climate change (Mao \& Wang 2011). Both correlation studies and PCA analysis based on observation of such traits showed relationship within vascular bundle traits, epidermal traits, and cross-section area traits that significantly varied and demonstrated that each part of the needle was relatively independent. It is interesting to observe that all exotic species (except $P$. taeda) show similarities among each other and exhibit variations when compared with native species (Fig. 3). Comparison between our dendograms based on a "nearest neighbor method" (squared Euclidean distance) using nine anatomical traits and that given by Gerandt et al. (2005) (Fig. 5) using chloroplast DNA for molecular phylogeny confirms the similarity among $P$. greggii and P. patula as well as between $P$. elliottii and $P$. echinata. It also confirms the similarity among $P$. merkusii, $P$. roxburghii and $P$. thunbergii. However, position of $P$. wallichiana, $P$. kesya and $P$. taeda shows variability when their relationship with other species was studied using anatomical traits, to that of molecular phylogeny (Figs. $3 \& 5$ ). Our results are comparable to other researches on molecular phylogeny where chloroplast based markers have been used (Wang et al. 1999, Syring et al. 2005, Leon et al. 2013, Olsson et al. 2018). PCA visualizes that NW (needle width), NT (needle thickness), VBT (vascular bundle thickness) and ENT (endodermal thickness) show similarity in $P$. roxburghii and $P$. taeda while C+ET (cuticular plus epidermal thickness), VBW (vascular bundle width), ENW (endodermal width) and RCD (resin canal diameter) show correlation in P. merkusii, P. echinata and P. taeda.

\section{Conclusions}

We found that variable needle anatomical traits exhibit great adherence to the molecular phylogeny of Pinus also attempted through chloroplast gene sequences and other markers earlier and provided reasonable evidence for classifying the genus upto subgenera, sections, and subsections level. However a large number of Pinus species are still anatomically not well studied or lack detailed anatomical explanations. The micromeasurement of various anatomical traits and 


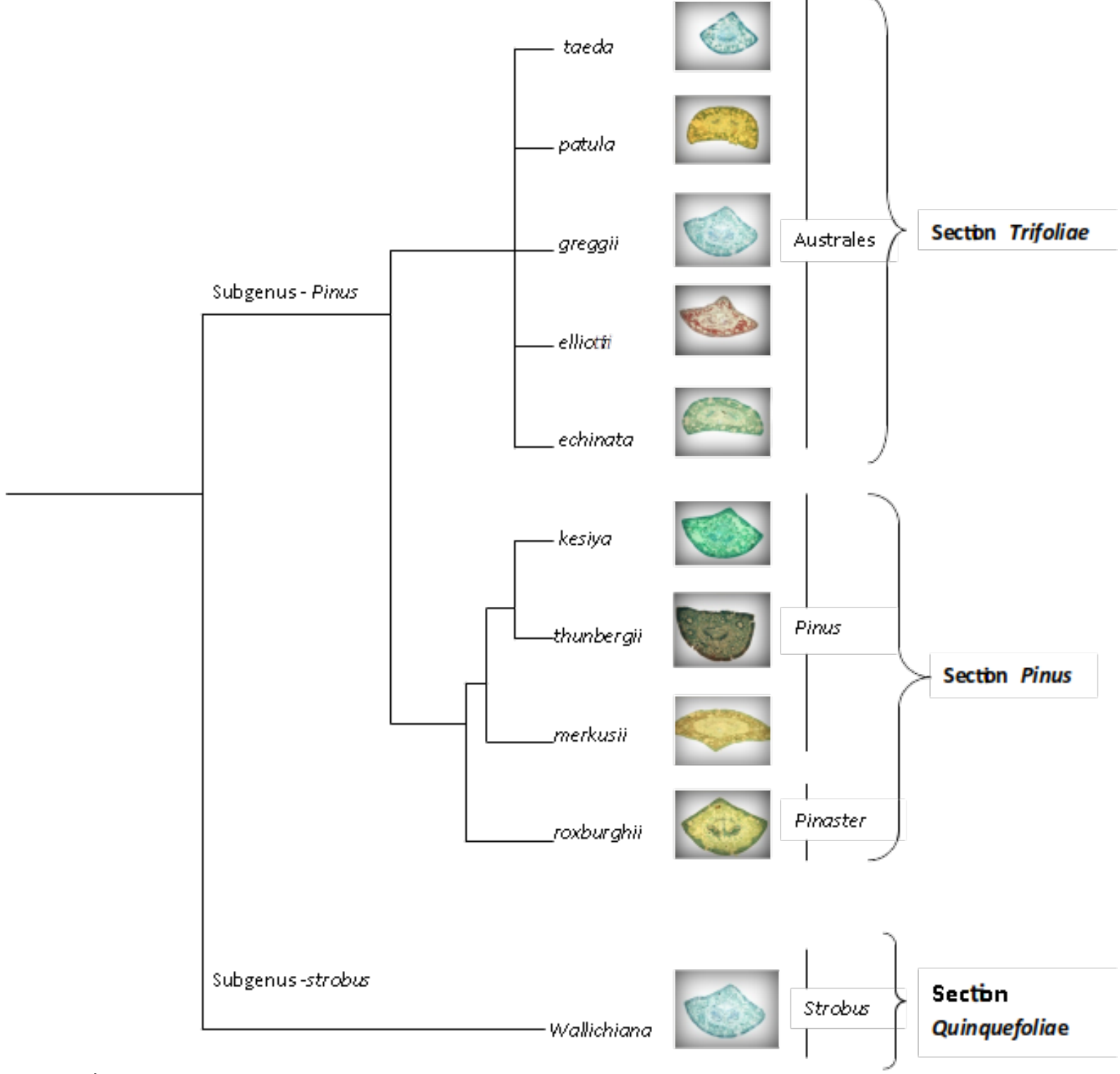

Figura 5. Árbol filogenético que muestra la estructura de la aguja de especies de Pinus seleccionadas (modificado de Gernandt et al. 2005) Figure 5. Phylogenetic tree showing the needle structure of selected Pinus species (modified from Gernandt et al. 2005).

other parameters like number and position of resin ducts, the position of vascular bundles, shape, and structure of leaves in cross section have great systematic value and are important for phylogenetic studies and classification of the genus Pinus as it has been shown in this study Further studies involving as many species as possible, including both subgenera and all their sections and subsections are highly recommended for establishing a database for a full proof classification and identification of this genus.

\section{Acknowledgment}

We are grateful to the University Grant Commission (UGC, India) for financial support provided by a grant to Lav Singh (Ref: 201314-NETJRF10212-83). The authors are also thankful to Head, Department of Botany, Lucknow University for providing necessary research facilities.

\section{References}

Abrams MD \& Kubiske ME. 1990. Leaf structural characteristics of 31 hardwood and conifer tree species in central Wisconsin: Influence of light regime and shade-tolerance rank. Forest Ecology and Management 31: 245-253. https://doi.org/10.1016/0378-1127 (90)90072-J

Dixit P, Singh L, Verma PC \& Saxena, G. 2016. Altitudinal Influences on Leaf and Wood Anatomy and its Ecological Implications in Cephalotaxus griffithii of Indian Himalayas. Journal of Biological and Chemical Research 33(1): 388-399. 
Jugrana AK, Bhatt ID, Rawal RS, Nandi SK \& Pande V. 2013. Patterns of morphological and genetic diversity of Valeriana jatamansi Jones in different habitats and altitudinal range of West Himalaya, India. Flora 208(1): 13-21. https://doi.org/10.1016/j.flora. 2012.12.003

Eckenwalder JE. 2009. Conifers of the World. Portland: Timber Press.

Farjon A. 1984. Pines: drawings and descriptions of the genus Pinus. Leiden: EJ Brill and W Backhuys.

Farjon A. 2005. Pines: drawings and description of the genus Pinus. Leiden: Brill.

Federica B \& Ruzin SE. 2000. Plant Micro technique and Microscopy. New York: Oxford University Press.

Gaussen H, Heywood VH \& Chater AO. 1993. Pinus L. In: Flora Europaea vol 1, 2nd (Tutin TG, Burges NA, Chater AO, Edmondson JR, Heywood VH, Moore DM, . . ., Webb DA, eds). Cambridge: Cambridge University Press, pp. 40-44.

Gernandt DS, Lopez GG,Garcia SO \& Liston A. 2005.Phylogeny and classification of Pinus. Taxon 54: 29-42. https://doi.org/10.2307/25065300

Ghimire B, Kim M, Lee JH \& Heo K.2014.Leaf anatomy of Pinus thunbergii Parl. (Pinaceae) collected from different regions of Korea. Korean Journal of Plant Taxonomy 44 (2): 91-99. https://doi.org/10.11110/ kjpt.2014.44.2.91

Kaundun SS \& Lebreton P. 2010.Taxonomy and systematics of the genus Pinus based on morphological, biogeographical and biochemical characters. Plant Systematics and Evolution 284: 1-15. https://doi.org/ 10.1007/s00606-009-0228-y

Legoshchina O, Neverova O \& Bykov A. 2013. Variability of the anatomical structure of Picea obovata Ledeb. Needles under the influence of emissions from the industrial zone of Kemerovo. Contemporary Problems of Ecology 6: 555-560. https://doi.org/10.1134/ $\underline{\mathrm{S} 1995425513050065}$

Leon SH, Gernandt DS, Rosa JA \& Barbolla LZ. 2013. Phylogenetic Relationships and Species Delimitation in Pinus Section Trifoliae Inferrred from Plastid DNA. PLOS ONE 8(7):e70501. https://doi.org/10.1371/ journal.pone.0070501

Little EL \& Critchfield WB. 1969. Subdivision of the genus Pinus (Pines). Washington, DC: USDA Forest Service Miscellaneous Publication.

Mao JF \& Wang XR. 2011. Distinct niche divergence characterizes the homoploid hybrid speciation of
Pinus densata on the Tibetan Plateau. American Naturalist 177(4): 424-439. https://doi.org/10.1086/ $\underline{658905}$

Montesinos-Navarro A, Wig J, Pico FX \& Tonsor SJ. 2011. Arabidopsis thaliana populations show clinal variation in a climatic gradient associated with altitude. New phytologist 189: 282-294. https://doi.org/ 10.1111/j.1469-8137.2010.03479.x

Nobis MP, Traiser C \& Roth NA. 2012. Latitudinal variation in morphological traits of the genus Pinus and its relation to environmental and phylogenetic signals. Plant Ecology \& Diversity 5: 1-11. https:// doi.org/10.1080/17550874.2012.687501

Olsson S, Grivet D \& Vian JC. 2018.Species-diagnostic markers in the genus Pinus: evaluation of the chloroplast regions matK and ycf1. Forest system 27:1-11. https://doi.org/10.5424/fs/2018273-13688

Price RA, Liston A \& Strauss SH. 1998. Phylogeny and systematics of Pinus. In: Ecology and biogeography of Pinus (Richardson DM, ed.). Cambridge: Cambridge University Press, pp. 49-68.

Richardson DM \& Rundel PW. 1998. Ecology and biogeography of Pinus: an introduction. In: Ecology and biogeography of Pinus (Richardson DM, ed.). Cambridge: Cambridge University Press, pp. 3-48.

Sharma A, Sharma L \& Goyal R. 2018. A Review on Himalayan Pine Species: Ethnopharmacological, Phytochemical and Pharmacological Aspects. Pharmacognosy Journal 10(4):611-619. https://doi.org/ 10.5530/pj.2018.4.100

Syring J, Willyard A, Cronn R, \& Liston A.2005. Evolutionary relationshipamong Pinus (Pinaceae) subsections inferred from multiple low-copy nuclear loci. American Journal of Botany 92(12): 2086-2100. https://doi.org/10.3732/ajb.92.12.2086

Wang XR,Tsumura Y, Yoshumaru H, Nagasaka K \& Szmidt AE. 1999. Phylogenetic relationships of Eurasian Pines (Pinus, Pinaceae) based on Chloroplast Rbc L, MATK, Rpl20-Rps18 SPACER, and TRNV intron sequences. American Journal of Botany. 86: 1742-1753. https://doi.org/10.2307/ $\underline{2656672}$

Xing FQ, Mao JF, Meng JX, Dai JF, Zhao W, Liu H, . . Li Y. 2014. Needle morphological evidence of the homoploid hybrid origin of Pinus densata based on analysis of artificial hybrids and the putative parents, Pinus tabuliformis and Pinus yunnanensis. Ecology and Evolution 4:1890-1902. https://doi.org/10.1002/ ece3.1062 